\title{
KAJIAN AKTIVITAS INDEKS GLIKEMIK BROWNIES KUKUS SUBSTITUSI TEPUNG UBI JALAR TERMODIFIKASI
}

\author{
Sefanadia Putri \\ Jurusan Gizi Poltekkes Tanjungkarang \\ Email: sefanadia@gmail.com
}

\begin{abstract}
Study on Activities Glycemic Index Brownies Substituted by Modified Sweet Potato Flour. Sweet potato is a source of carbohydrates with a low glycemic index. That could aimed to substitute wheat flour in making brownies. These study purposes were to determine the organoleptic characterictic, glycemic index and glycemic load of Modified sweet potato Flour. It was an experimental laboratory research with true design-experiment. The experiment was arranged in a randomized complete block design (RCBD) with four replications. There were 5 formula, that were ratio of modified sweet potato flour to wheat flour 0: 100 (F1), 25: 75 (F2), 50: 50 (F3), 75: 25 (F4) and 100: 0 (F5). It was to get a product that could be accepted by organoleptic tests, brownies products were most preferred. The most preferred brownies was tested the glycemic index and glycemic load. Statistical analysis showed that the concentration of modified sweet potato flour were not significantly affected the color, flavor, aroma and texture, but significant effected on the overall acceptance of brownies. Formula 3 was the most preferred modified sweet potato flour ratio. Glycemic index and glycemic load test of the most preferred formula were $53.76 \%$ (lower) and $19.15 \%$, respectively.
\end{abstract}

Keywords: Brownies, Modified sweetpotato flour, Glycemic index

\begin{abstract}
Abstrak: Kajian Aktivitas Indeks Glikemik Brownies Kukus Substitusi Tepung Ubijalar Termodifikasi. Ubi jalar merupakan sumber karbohidrat dengan indeks glikemik rendah.Tepung ubi jalar ungu termodifikasi merupakan tepung yang bertujuan untuk mensubstitusi tepung terigu dalam pembuatan brownies kukus.Tujuan dari penelitian ini Untuk mengetahui sifat organoleptik, indeks glikemik serta beban glikemik brownies kukus substitusi tepung ubi jalar ungu termodifikasi. Penelitian ini merupakan penelitian eksperimental laboratorium dengan desain trueexperiment. Percobaan disusun dalam Rancangan Acak Kelompok Lengkap (RAKL) dengan empat ulangan. Perlakuan yakni substitusi tepung ubi jalar termodifikasi dengan tepung terigu yaitu 0:100 (F1), 25:75 (F2), 50:50 (F3), 75:25 (F4)dan 100:0(F5) untuk mendapatkan suatu produk yang dapat diterima berdasarkan uji organoleptik yang paling disukai. Brownies kukus yang paling disukai kemudian dilakukan pengujian Indeks glikemik dan beban glikemik. Hasil uji statistik menunjukkan bahwa konsentrasi substitusi tepung ubi jalar ungu termodifikasi tidak berpengaruh nyata terhadap warna, rasa, aroma dan tekstur namun berpengaruh nyata terhadap penerimaan keseluruhan brownies kukus. Substitusi tepung ubi jalar ungu pada brownies kukus yang paling disukai didapat pada formula 3. Indeks glikemik brownies kukus substitusi tepung ubi jalar ungu termodifikasi yang paling disukai sebesar 53,76\% (rendah). Beban glikemik brownies kukus substitusi tepung ubi jalar ungu termodifikasi yang paling disukai sebesar 19,15\% (sedang).
\end{abstract}

Kata kunci: Brownies, Ubi jalar termodifikasi, Indeks Glikemik

Dewasa ini, pergeseran pola penyakit terus terjadi. Penyakit-penyakit degeneratif seperti kardiovaskuler, hipertensi, dan diabetes melitus menjadi penyebab utama kematian di negara-negara maju maupun negara berkembang. Penyakit ini sangat terkait dengan pola perilaku termasuk pola makan. Salah satu cara untuk mengontrol gula darah adalah dengan pengaturan diet. Upaya ini dapat dilakukan melalui pendekatan indeks glikemik pangan. Konsep indeks glikemik merupakan pendekatan yang relatif baru untuk memilih pangan yang baik, khususnya pangan berkarbohidrat. Konsep indeks glikemik menekankan pada pentingnya mengenal pangan (karbohidrat) berdasarkan kecepatannya menaikkan kadar glukosa darah (Rimbawan dan Siagian, 2004).

Salah satu bahan pangan lokal yang merupakan sumber karbohidrat dengan indeks glikemik rendah adalah ubi jalar (Brand et al., 1985) sehingga dapat digunakan sebagai alternatif diet untuk mencegah terjadinya gangguan toleransi gula darah. Menurut Badan Pusat Statistik (2013), produktivitas ubi jalar ungu di Indonesia mencapai $142,27 \mathrm{kw} / \mathrm{Ha}$ sedangkan khusus daerah Lampung mencapai 
97,48 kw/Ha. Ubi jalar mengandung energi paling tinggi (194 MJ/ha/hari) di antara tanaman pangan lainnya dan merupakan sumber gizi yang baik (vitamin A, vitamin $\mathrm{C}$, kalium, besi dan fosfor) (Widodo dan Ginting, 2004). Ubi jalar merupakan sumber karbohidrat yang memiliki kandungan antioksidan dan serat pangan yang tinggi.

Keberadaan ubi jalar telah dikenal baik oleh masyarakat Indonesia, bahkan di beberapa daerah dijadikan makanan pokok. Namun minat masyarakat untuk mengkonsumsi pangan asal ubi jalar masih rendah. Hal tersebut disebabkan pengolahan ubi jalar di Indonesia masih terbatas dan sederhana, seperti direbus/dikukus, dipanggang, atau digoreng. Selain itu, timbul persepsi bahwa ubi jalar merupakan bahan pangan inferior yang tidak sekelas dengan gandum atau jagung (Lutfika, 2006). Ubi jalar segar memiliki kadar air yang tinggi sehingga mudah rusak bila tidak segera dilakukan penanganan pasca panen (Suismono, 2001). Teknologi pengolahan tepung merupakan salah satu teknologi alternatif yang diharapkan mampu mengatasi berbagai persoalan di atas. Pengolahan tepung merupakan salah satu proses pengawetan yang dianjurkan terutama dari bahan umbiumbian, buah-buahan dan serealia non beras.

Salah satu produk diversifikasi pangan setengah jadi ubi jalar yakni tepung ubi jalar termodifikasi dengan menggunakan metode fermentasi bakteri asam laktat yang berupa Acetobacter xylinum, sehingga dapat dimanfaatkan dengan berbagai macam hasil olahan berbasis tepung terigu. Menurut Saxena et al., (1995), perlakuan pemberian bakteri Acetobacter xylinum dalam proses pembuatan dengan menggunakan metode fermentasi memiliki kemampuan untuk mempolimerisasi glukosa sehingga mampu mengubah menjadi selulosa. Menurut Gibson (2010), karbohidrat kompleks memiliki respon glukosa yang lebih kecil dalam darah. Karbohidrat yang terkandung dalam pangan tersebut akan dipecah dengan lambat sehingga pelepasan glukosa ke dalam darah berjalan lambat (Rimbawan dan Siagian, 2004). Pengolahan tepung ubi jalar ungu termodifikasi juga bertujuan untuk meningkatkan dayaguna dan daya tahan dalam bentuk produk kering sehingga dapat memperpanjang daya simpan, selain itu pembuatan tepung ubi jalar ungu termodifikasi dapat menjadi penunjang penggunaan tepung terigu yang umum digunakan masyarakat (Sukarsih, 2009).

Persaingan industri makanan khususnya cake, brownies merupakan panganan yang banyak dilirik oleh konsumen. Berdasarkan data
Statistik Konsumsi Pangan Tahun 2015, konsumsi kue basah pada Tahun 2015 mencapai $1,245 \mathrm{~kg} / \mathrm{Kapita} / \mathrm{Minggu}$. Tepung ubi jalar ungu termodifikasi merupakan tepung yang bertujuan untuk mensubstitusi tepung terigu dalam pembuatan brownies kukus sehingga menghasilkan produk brownies kukus dengan sifat organoleptik yang disukai oleh masyarakat. Hasil penelitian substitusi tepung bengkuang terhadap kualitas brownies kukus yang dilakukan oleh Pratiwi (2015), variasi konsentrasi substitusi tepung bengkuang yang digunakan adalah 0\%, $25 \%, 50 \%, 75 \%$ dan $100 \%$, didapat hasil bahwa perlakuan yang paling disukai pada konsentrasi 25\%. Penelitian ini difokuskan pada kajian indeks glikemik brownies kukus yang disubstitusi oleh tepung ubi jalar ungu termodifikasi. Produk yang dihasilkan diharapkan menjadi makanan sehat dengan indeks glikemik yang lebih rendah dan citarasa yang enak sehingga menjadi makanan alternatif yang dapat mencegah terjadinya gangguan toleransi gula darah. Selain itu, diharapkan produk olahan tersebut dapat meningkatkan nilai tambah ubi jalar sehingga dapat menjadi komoditas alternatif dalam rangka diversifikasi pangan. Diketahuinya sifat organoleptik, indeks glikemik serta beban glikemik brownies kukus substitusi tepung ubi jalar ungu termodifikasi.

\section{METODE PENELITIAN}

Penelitian ini merupakan penelitian eksperimental laboratorium dengan desain trueexperiment. Percobaan disusun dalam Rancangan Acak Kelompok Lengkap (RAKL) dengan empat ulangan. Perlakuan yakni substitusi tepung ubi jalar termodifikasi dengan tepung terigu yaitu 0:100 (F1), 25:75 (F2), 50:50 (F3), 75:25 (F4) dan 100:0 (F5) untuk mendapatkan suatu produk yang dapat diterima berdasarkan uji organoleptik yang paling disukai. Brownies kukus yang paling disukai kemudian dilakukan pengujian Indeks glikemik (BPOM, 2011). Penentuan indeks glikemik dan beban glikemik brownies kukus menggunakan roti tawar sebagai standar. Pada uji indeks glikemik dilakukan dengan menggunakan manusia sebagai objek penelitian. Kriteria inklusi sampel dalam penelitian ini adalah: sehat, non-diabetes, memiliki kadar glukosa puasa normal (70-120 mg/dl), memiliki nilai Indeks Massa Tubuh (IMT) dalam kisaran normal $18.5-25 \mathrm{~kg} / \mathrm{m}^{2}$.

Adapun kriteria ekslusi sampel adalah mengkonsumsi obat-obatan, perokok. Cara pengukuran glukosa darah selama 2 jam 
postprandial yakni pengambilan sampel darah relawan dilakukan setiap selang 30 menit sekali yaitu 0 menit (kadar gula darah puasa), 30 menit, 60 menit, 90 menit, dan 120 menit setelah mengkonsumsi brownies kukus. Sedangkan penentuan beban glikemik dengan cara perhitungan kandungan karbohidrat brownies kukus metode by difference yang terlebih dahulu dilakukan analisa proksimat (kadar air, kadar abu, kadar protein, kadar lemak, serat pangan) brownies kukus yang paling disukai.

Penelitian dilaksanakan pada bulan MeiNovember 2016. Uji organoleptik dilaksanakan di Laboratorium Ilmu Teknologi Pangan Jurusan Gizi Poltekkes Tanjungkarang, penentuan Indeks Glikemik dilakukan di Jurusan Analis Kesehatan Poltekkes Tanjungkarang, pengujian analisa proksimat (air, abu, protein, lemak serta serat) dilakukan di Laboratorium Teknologi Pangan Politeknik Negeri Lampung.

\section{Prosedur Kerja Tepung Ubi Jalar Termodifikasi}

Sortasi dan penimbangan ubi jalar ungu, kemudian pengupasan kulit ubi jalar ungu dan ditampung dalam bak atau ember yang berisi air sehingga tidak menimbulkan warna kecokelatan. Selanjutnya, pencucian ubi jalar ungu menggunakan air bersih. Ubi jalar yang telah dicuci bersih kemudian dilakukan pemotongan tipis berbentuk chips berukuran kurang lebih 0,2$0,3 \mathrm{~cm}$. Fermentasi/ Perendaman chips ubi jalar ungu menggunakan drum plastik atau ember yang berisi air, kemudian dilarutkan bakteri Acetobacter xylinum dengan konsentrasi 5\% dari volume chips dan air. Perendaman chips ubi jalar ungu diupayakan tenggelam oleh air. Fermentasi dilakukan selama 30 jam. Setelah proses fermentasi selesai, dilakukan pencucian kembali untuk menghilangkan sifat asam pada chips ubi jalar ungu hingga tidak berasa dan tidak berbau. Kemudian chips ditiriskan dengan menggunakan tampah dari anyaman bambu.

Chips ubi jalar ungu yang telah difermentasi ditiriskan dan dijemur dibawah sinar matahari dengan suhu panas normal atau menggunakan metode oven pada suhu $60^{\circ} \mathrm{C}$ hingga mencapai kadar air $13 \%$ atau chips sudah mulai kering dan mudah dihancurkan.

Proses penepungan dilakukan setelah chips ubi jalar ungu kering, selanjutnya dilakukan proses penepungan menggunakan food grinder. Pengayakan dilakukan untuk menghasilkan tepung yang halus. Pengayakan dilakukan secara manual menggunakan saringan dengan mesh 80 .

\section{Prosedur Kerja Brownies Kukus Substitusi Tepung Ubi Jalar Termodifikasi}

Pembuatan brownies

kukus menggunakan 5 formulasi tepung ubi jalar ungu termodifikasi yaitu 0:100 (F1), 25:75 (F2), 50:50 (F3), 75:25 (F4) dan 100:0 (F5). Proses pertama kali adalah menghomogenisasikan $300 \mathrm{~g}$ margarin, $75 \mathrm{~g}$ cokelat bubuk, dan $250 \mathrm{~g}$ gula pasir dengan menggunakan mixer selama 30 detik dengan kecepatan tinggi. Kemudian masukan $300 \mathrm{~g}$ telur (6 butir @ 050 g) satu-persatu lalu mixer kembali selama 2 menit dengan kecepatan tinggi. Tambahkan baking powder $2 \mathrm{~g}$ dan $\mathrm{Sp} 1 \mathrm{~g}$ dicampur dengan mixer selama 30 detik dengan kecepatan tinggi. Kemudian masukan formulasi tepung ubi jalar ungu termodifikasi dan tepung terigu dengan perlahan-lahan mixer dengan kecepatan rendah selama 1 menit. Setelah selesai adonan dimasukan kedalam loyang berukuran $15 \times 30 \times 3 \mathrm{~cm}$, langkah terakhir adalah mengkukus adonan brownies tersebut selama 30 menit dengan air mendidih.

Analisis data menggunakan uji Analysis of Variance (Anova), jika data yang didapat tidak memenuhi syarat dari uji Anova maka analisis bivariat dilanjutkan dengan menggunakan uji Kruskalwalis. Analisis data kandungan Indeks Glikemik dan Beban Glikemik pada brownies kukus yang disubstitusi tepung ubi jalar termodifikasi menggunakan univariat dan data disajikan dalam bentuk grafik, sedangkan data beban glikemik brownies kukus substitusi ubi jalar termodifikasi disajikan dalam bentuk tabel.

\section{HASIL}

\section{Uji Organoleptik}

Pengamatan yang dilakukan pada brownies kukus substitusi tepung ubi jalar termodifikasi adalah untuk mengetahui sifat organoleptik sehingga dapat diketahui kualitas organoleptik yang paling disukai dan indeks glikemik serta beban glikemik brownies kukus substitusi tepung ubi jalar ungu termodifikasi.

\section{a. Warna}

Hasil uji organoleptik terhadap warna pada produk brownies kukus substitusi tepung ubi jalar ungu termodifikasi dapat dilihat pada Tabel 1. 
Tabel 1. Pengaruh Substitusi Tepung Ubi Jalar Ungu Termodifikasi terhadap Warna Brownies Kukus

\begin{tabular}{|c|c|c|c|}
\hline Formulasi & $\begin{array}{c}\text { Median } \\
(\text { min-maks) }\end{array}$ & Rerata \pm s.b. & $\begin{array}{c}p- \\
\text { value }\end{array}$ \\
\hline F1 & $3(1-5)$ & $\begin{array}{r}3,275 \\
\pm 0,99333 \\
\end{array}$ & \multirow{5}{*}{0,235} \\
\hline $\mathrm{F} 2$ & $4(1-5)$ & $\begin{array}{r}3,5375 \\
\pm 0,91325 \\
\end{array}$ & \\
\hline F3 & $4(1-5)$ & $\begin{array}{r}3,5625 \\
\pm 0,79307 \\
\end{array}$ & \\
\hline F4 & $3,5(1-5)$ & $\begin{array}{r}3,55 \\
\pm 0,79396\end{array}$ & \\
\hline F5 & $4(2-5)$ & $\begin{array}{r}3,5375 \pm \\
0,81043\end{array}$ & \\
\hline
\end{tabular}

Hasil uji statistik kruskal-wallis diperoleh nilai $p=0,235$ berarti pada alpha 5\% dapat disimpulkan bahwa tidak terdapat pengaruh secara nyata substitusi tepung ubi jalar ungu termodifikasi terhadap warna brownies kukus.

\section{b. Rasa}

Hasil uji organoleptik terhadap rasa pada produk brownies kukus substitusi tepung ubi jalar ungu termodifikasi dapat dilihat pada Tabel 2. Hasil uji statistik kruskal-wallis diperoleh nilai $p=0,057$ berarti pada alpha $5 \%$ dapat disimpulkan bahwa tidak terdapat pengaruh secara nyata substitusi tepung ubi jalar ungu termodifikasi terhadap rasa brownies kukus.

Tabel 2. Pengaruh Substitusi Tepung Ubi Jalar Ungu Termodifikasi terhadap Rasa Brownies Kukus

\begin{tabular}{crrr}
\hline Formulasi & $\begin{array}{c}\text { Median } \\
\text { (min-maks) }\end{array}$ & Rerata \pm s.b. & $\begin{array}{c}\boldsymbol{p} \text { - } \\
\text { value }\end{array}$ \\
\hline F1 & $3(2-5)$ & 3,3125 & \\
& & $\pm 0,80495$ & \\
F2 & $4(1-5)$ & 3,4375 & \\
& & $\pm 0,85453$ & 0 \\
& & & \\
F3 & $4(1-5)$ & $3,65 \pm 0,8283$ \\
\hline F4 & $3(2-5)$ & $3,35 \pm 0,8283$ \\
F5 & $3(1-5)$ & $3,35 \pm$ & \\
& & 0,91541 & \\
\hline
\end{tabular}

\section{c. Aroma}

Hasil uji organoleptik terhadap aroma pada produk brownies kukus substitusi tepung ubi jalar ungu termodifikasi dapat dilihat pada Tabel 3.
Tabel 3. Pengaruh Substitusi Tepung Ubi Jalar Ungu Termodifikasi Terhadap Aroma Brownies Kukus

\begin{tabular}{crrr}
\hline Formulasi & $\begin{array}{c}\text { Median } \\
\text { (min-maks) }\end{array}$ & Rerata \pm s.b. & $\begin{array}{c}\boldsymbol{p} \text { - } \\
\text { value }\end{array}$ \\
\hline F1 & $3(2-5)$ & $3,4 \pm 0,70442$ & \\
\cline { 1 - 3 } F2 & $3(2-5)$ & $3,35 \pm 0,69537$ & \\
\cline { 1 - 3 } F3 & $4(2-5)$ & 3,525 & \multirow{2}{*}{0,267} \\
& & $\pm 0,69309$ \\
\cline { 1 - 3 } F4 & $3(2-5)$ & $3,25 \pm 0,77132$ & \\
\cline { 1 - 2 } F5 & $3(1-5)$ & $3,3875 \pm$ & \\
& & 0,8641 & \\
\hline
\end{tabular}

Hasil uji statistik kruskal-wallis diperoleh nilai $p=0,267$ berarti pada alpha 5\% dapat disimpulkan bahwa tidak terdapat pengaruh secara nyata substitusi tepung ubi jalar ungu termodifikasi terhadap aroma brownies kukus.

\section{d. Tekstur}

Hasil uji organoleptik terhadap tekstur pada produk brownies kukus substitusi tepung ubi jalar ungu termodifikasi dapat dilihat pada Tabel 4. Hasil uji statistik kruskal-wallis diperoleh nilai $p=0,101$ berarti pada alpha 5\% dapat disimpulkan bahwa tidak terdapat pengaruh secara nyata substitusi tepung ubi jalar ungu termodifikasi terhadap tekstur brownies kukus.

Tabel 4. Pengaruh Substitusi Tepung Ubi Jalar Ungu Termodifikasi terhadap Tekstur Brownies Kukus

\begin{tabular}{crrr}
\hline Formulasi & $\begin{array}{c}\text { Median } \\
\text { (min-maks) }\end{array}$ & Rerata \pm s.b. & $\begin{array}{c}\boldsymbol{p} \text { - } \\
\text { value }\end{array}$ \\
\hline F1 & $3(2-5)$ & 3,325 & \\
& & $\pm 0,85351$ & \\
F2 & $3(1-5)$ & 3,1625 & \\
& & $\pm 0,86337$ & \\
F3 & $3,5(1-5)$ & 3,4125 & 0,101 \\
& & $\pm 0,92358$ & \\
F4 & $3(1-4)$ & 3,0375 & \\
& & $\pm 0,81821$ & \\
\cline { 1 - 3 } F5 & $3(1-5)$ & $3,2375 \pm 0,892$ & \\
\hline
\end{tabular}

\section{e. Penerimaan Keseluruhan}

Hasil uji organoleptik terhadap penerimaan keseluruhan pada produk brownies kukus substitusi tepung ubi jalar ungu termodifikasi dapat dilihat pada Tabel 5 . 
Tabel 5. Pengaruh Substitusi Tepung Ubi Jalar Ungu Termodifikasi terhadap Penerimaan Keseluruhan Brownies Kukus

\begin{tabular}{crrr}
\hline Formulasi & $\begin{array}{c}\text { Median } \\
\text { (min-maks) }\end{array}$ & Rerata \pm s.b. & $\begin{array}{c}\boldsymbol{p} \text { - } \\
\text { value }\end{array}$ \\
\hline F1 & $4(2-5)$ & 3,5 & \\
& & $\pm 0,72914$ & \\
F2 & $3,5(2-5)$ & 3,4875 & \\
& & $\pm 0,65591$ & \\
F3 & $4(1-5)$ & 3,6875 & 0,036 \\
& & $\pm 0,80495$ & \\
F4 & $3(1-5)$ & 3,3875 & \\
& & $\pm 0,75463$ & \\
F5 & $3(1-5)$ & $3,3625 \pm$ \\
& & 0,8456 & \\
\hline
\end{tabular}

Hasil uji statistik kruskal-wallis diperoleh nilai $p=0,036$ berarti pada alpha 5\% dapat disimpulkan bahwa terdapat pengaruh secara nyata substitusi tepung ubi jalar ungu termodifikasi terhadap penerimaan keseluruhan brownies kukus.

\section{Indeks Glikemik (IG) dan Beban Glikemik (BG)}

\section{a. Karakteristik Subjek}

Subjek terdiri dari 10 orang sukarelawan yang telah menandatangani informed consent dengan status gizi normal (IMT 18,5-22,9 kg/m²) dan GDP antara 70-120 mg/dl, serta umur berkisar 21 tahun. Karakteristik subjek penelitian dapat dilihat pada tabel 6 .

Tabel 6. Karakteristik Subjek Penelitian

\begin{tabular}{|c|c|c|c|c|c|}
\hline Subjek & Umur (Thn) & BB (kg) & TB (cm) & IMT $\left(\mathrm{kg} / \mathrm{m}^{2}\right)$ & GDP (mg/dl) \\
\hline 1 & 21 & 53 & 169 & 18,56 & 71 \\
\hline 2 & 21 & 52,8 & 152 & 22,85 & 83 \\
\hline 3 & 21 & 60 & 159,8 & 23,5 & 80 \\
\hline 4 & 21 & 51 & 155 & 21,23 & 95 \\
\hline 5 & 21 & 55 & 155 & 22,9 & 95 \\
\hline 6 & 21 & 49 & 157 & 19,88 & 93 \\
\hline 7 & 21 & 62 & 160 & 24,22 & 100 \\
\hline 8 & 21 & 54 & 158 & 21,63 & 80 \\
\hline 9 & 21 & 54,4 & 163 & 20,47 & 85 \\
\hline 10 & 21 & 52 & 165 & 19,1 & 97 \\
\hline Rata-rata & 21 & 54,32 & 159,38 & 21,43 & 87,9 \\
\hline
\end{tabular}

Berdasarkan Tabel 6 diketahui bahwa ratarata umur subjek adalah 21 tahun dengan ratarata IMT sebesar 21,4331 $\left(\mathrm{kg} / \mathrm{m}^{2}\right)$ dan GDP 87,9 $\mathrm{mg} / \mathrm{dl}$. Hal ini telah sesuai dengan kriteria inklusi subjek.

\section{b. Penentuan Jumlah Pangan Uji}

Berdasarkan data hasil uji organoleptik, bahan pangan yang akan dinilai indeks glikemiknya adalah brownies kukus substitusi tepung ubi jalar termodifikasi Formula 3 dengan perbandingan tepung terigu:tepung ubi jalar termodifikasi $=100: 100$, sedangkan makanan standar yang digunakan dalam penelitian ini didapatkan dalam bentuk jadi dan siap saji. Dalam hal ini peneliti tidak melakukan proses pengolahan tambahan terhadap makanan standar. Bahan pangan standar yang digunakan sebagai pembandingnya adalah roti tawar. Masingmasing bahan harus mengandung 50 available carbohydrate yang dapat diketahui dari uji karbohidrat by different. Komposisi zat gizi makanan standar dan makan uji dalam satu porsi dapat dilihat pada tabel 7 .

Tabel 7. Hasil Analisis kandungan zat gizi per $100 \mathrm{~g}$

$$
\text { Rerata Kandungan Gizi (\%) }
$$

\section{$\begin{array}{llllll}\text { Bahan pangan uji } & \text { Air } & \text { Abu } & \text { Protein Lemak } & \text { Serat Kasar Karbohidrat }\end{array}$}

\begin{tabular}{lrrrrrc} 
& & & & \multicolumn{2}{c}{ Total } \\
\hline Roti Tawar $^{(*)}$ & - & - & 9,46 & 4,054 & - & 50 \\
\hline Brownies kukus formula 3 & 27,49 & 1,36 & 9,88 & 20,75 & 5,25 & 35,62
\end{tabular}

Ket :

$\left.{ }^{*}\right)$ : Informasi nilai gizi sari roti tawar 



\section{c. Respon Glukosa Darah}

Rata-rata hasil respon

subjek terhadap pemberian glukosa darah

roti tawar dan brownies kukus formula 3 dapat dilihat pada tabel 8 .

Tabel 8.Nilai Rata-Rata Kadar Glukosa Darah (mg/dl)

\begin{tabular}{lccccc}
\hline Bahan makanan & \multicolumn{5}{c}{ Waktu (menit) } \\
\cline { 2 - 6 } & $\mathbf{0}$ & $\mathbf{3 0}$ & $\mathbf{6 0}$ & $\mathbf{9 0}$ & $\mathbf{1 2 0}$ \\
\hline Roti tawar & $87,9 \pm 9,422$ & $115,7 \pm 7,288$ & $124,5 \pm 11,008$ & $116,8 \pm 16,075$ & $96,7 \pm 8,616$ \\
\hline $\begin{array}{l}\text { Brownies kukus } \\
\text { formula 3 }\end{array}$ & $85,1 \pm 6,244$ & $102 \pm 9,125$ & $100,8 \pm 7,927$ & $98 \pm 8,273$ & $95,5 \pm 8,182$ \\
\hline
\end{tabular}

Berdasarkan tabel 8 diketahui bahwa puncak kenaikan kadar gula darah untuk roti tawar terjadi pada menit ke- 60 setelah makan dan menurun secara bertahap pada menit-menit selanjutnya. Lebih detilnya nilai presentase kenaikan atau penurunan dapat dilihat pada tabel 9. Pada Tabel 9 Tanda (+) atau tidak terdapat tanda menunjukkan besar kenaikan kadar glukosa darah sedangkan tanda menunjukkan besar penurunan.

Tabel 9. Kenaikan/Penurunan Kadar Glukosa Darah

\begin{tabular}{|c|c|c|c|c|}
\hline \multirow[t]{2}{*}{$\begin{array}{c}\text { Bahan } \\
\text { makanan }\end{array}$} & \multicolumn{4}{|c|}{$\begin{array}{c}\text { Kenaikan/penurunan kadar } \\
\text { glukosa darah pada menit } \\
\text { ke - }\end{array}$} \\
\hline & 30 & 60 & 90 & 120 \\
\hline Roti tawar & 27,8 & 8,3 & $-7,7$ & $-20,1$ \\
\hline $\begin{array}{l}\text { Brownies kukus } \\
\text { formula } 3\end{array}$ & 16,9 & $-1,2$ & $-2,8$ & $-2,5$ \\
\hline
\end{tabular}

Semua nilai dengan satuan $\mathrm{mg} / \mathrm{dl}$. Bila dibandingkan dengan pemberian roti tawar, kenaikan kadar glukosa darah pada brownies kukus formula 3 terjadi pada menit 30 .

\section{d. Indeks Glikemik}

Hasil rata-rata Indeks glikemik dari 10 subjek dapat dilihat pada Tabel 10. Berdasarkan Tabel 10 diketahui bahwa Indeks glikemik Brownies kukus substitusi ubi jalar termodifikasi dengan kategori Rendah $(53,76 \%)$.

Tabel 10. Indeks glikemik brownies kukus substitusi ubijalar termodifikasi

\begin{tabular}{|c|c|c|c|}
\hline $\begin{array}{c}\text { Bahan } \\
\text { Pangan } \\
\text { Uji }\end{array}$ & $\begin{array}{c}\text { Luas Area } \\
\text { di Bawah } \\
\text { Kurva (cm) }\end{array}$ & $\begin{array}{c}\text { Indeks } \\
\text { Glikemik } \\
(\%)\end{array}$ & Kategori* \\
\hline $\begin{array}{l}\text { Roti } \\
\text { Tawar }\end{array}$ & 6819 & & \\
\hline $\begin{array}{l}\text { Brownies } \\
\text { kukus } \\
\text { formula } 3\end{array}$ & 3666 & $\begin{array}{l}53,76 \pm \\
29,675\end{array}$ & Rendah \\
\hline
\end{tabular}

\section{e. Beban Glikemik (BG)}

Tabel 11 menunjukkan bahwa dalam berat takaran saji $100 \mathrm{~g}$ BG brownies kukus Formula 3 sebesar 19,15.

\section{Tabel 11. Hasil Beban Glikemik Brownies} Kukus

\begin{tabular}{|c|c|c|c|c|}
\hline $\begin{array}{c}\text { Bahan } \\
\text { pangan } \\
\text { uji }\end{array}$ & IG & $\begin{array}{c}\text { Jumlah } \\
\text { takaran } \\
\text { saji (g) }\end{array}$ & $\begin{array}{c}\text { Karb } \\
\text { pertakaran } \\
\text { saji }(\mathbf{g}) \\
\end{array}$ & BG \\
\hline $\begin{array}{l}\text { Brownies } \\
\text { kukus } \\
\text { formula } 3\end{array}$ & 53,76 & 100 & 35,6217 & 19,15 \\
\hline
\end{tabular}

\section{PEMBAHASAN}

\section{Uji Organoleptik}

Ubi jalar yang telah mengalami proses pengolahan menjadi tepung ubi jalar termodifikasi sebagai bahan substitusi tepung terigu pada produk brownies kukus kemudian dilakukan pengujian organoleptik (hedonik). Uji organoleptik dilakukan untuk mengetahui tingkat kesukaan panelis pada produk brownies kukus substitusi tepung ubi jalar termodifikasi yang dihasilkan meliputi warna, rasa, aroma, tekstur dan penerimaan keseluruhan.

\section{a. Warna}

Secara umum semua formulasi brownies kukus substitusi tepung ubi jalar termodifikasi dapat diterima oleh panelis. Uji organoleptik warna brownies kukus berkisar antara 3,2753,5625 . Skor warna tertinggi $(3,5625)$ dihasilkan oleh formula 3 (brownies kukus substitusi tepung ubi jalar dengan perbandingan tepung terigu:tepung ubi jalar $=100: 100)$. Panelis menilai warna brownies kukus formula 3 disukai panelis. skor warna brownies kukus terendah $(3,275)$ dihasilkan oleh formula 1 (brownies kukus substitusi tepung ubi jalar dengan perbandingan tepung terigu:tepung ubi jalar $=$ 200:0). Tingkat skala kesukaan panelis adalah biasa saja terhadap warna dari produk brownies. 
Tingkat konsentrasi substitusi tepung ubi jalar termodifikasi tidak berpengaruh secara nyata terhadap warna brownies kukus. Hal ini diduga karena penambahan tepung cocoa atau cokelat bubuk pada pembuatan brownies kukus dengan konsentrasi yang sama pada setiap formulanya sedangkan tepung ubi jalar bewarna ungu muda yang tidak mempengaruhi hasil akhir dari brownies kukus. Warna brownies kukus substitusi tepung ubi jalar ungu termodifikasi yang dihasilkan berkisar antara cokelat muda sampai cokelat tua, semakin banyak konsentrasi substitusi tepung ubi jalar ungu termodifikasi pada brownies kukus maka warna semakin cokelat.

Warna cokelat pada brownies kukus dalam penelitian ini diduga disebabkan adanya pemberian bahan tambahan yang berupa bubuk cokelat dengan konsentrasi yang sama pada setiap formula pada produk pangan. Faktorfaktor yang mempengaruhi warna dari produk brownies adalah penggunaan gula, telur, cokelat. Warna tepung ubi jalar ungu memiliki warna lebih gelap dibandingkan tepung terigu. Ubi jalar juga mengandung senyawa antosianin, yaitu pigmen yang menyebabkan daging umbi berwarna ungu. Antosianin termasuk dalam kelompok flavonoid yang penyebarannya luas diantara spesies tanaman, merupakan pigmen berwarna merah, ungu hingga biru (Yuwono; dkk., 2010). Warna cokelat juga dimungkinkan karena adanya reaksi mailard selama proses pengukusan. Selama pengukusan terjadi reaksi maillard yaitu reaksi antara gula reduksi dengan gugus amina primer pada protein sehingga dihasilkan produk yang berwarna cokelat (Winarno, 2002).

\section{b. Rasa}

Uji organoleptik rasa brownies kukus berkisar antara 3,3125-3,65. Skor rasa tertinggi $(3,65)$ dihasilkan oleh formula 3 (brownies kukus substitusi tepung ubi jalar dengan perbandingan tepung terigu:tepung ubi jalar $=100: 100$ ). Panelis menilai rasa brownies kukus formula 3 disukai panelis. Semakin banyak penggunaan tepung ubi jalar ungu termodifikasi maka rasa manis akan meningkat. Hal ini diduga karena di dalam ubi jalar memiliki kandungan oligosakarida yang mempunyai rasa manis yaitu rafinosa. Kandungan rafinosa memiliki tingkat kemanisan 0,15 bila dibandingkan dengan kemanisan sukrosa yaitu 1,00 (Winarno, 2002).

Skor rasa brownies kukus terendah $(3,3125)$ dihasilkan oleh formula 4 (brownies kukus substitusi tepung ubi jalar dengan perbandingan tepung terigu:tepung ubi jalar $=$
150:50). Tingkat skala kesukaan panelis adalah biasa saja terhadap rasa dari produk brownies, hal ini dikarenakan rasa brownies kukus yang kurang begitu manis.

Tingkat konsentrasi substitusi tepung ubi jalar termodifikasi tidak berpengaruh secara nyata terhadap rasa brownies kukus. Hal ini diduga karena tepung ubi jalar ungu termodifikasi tidak memiliki rasa yang khas sehingga tidak berpengaruh terhadap rasa brownies. Pada pembuatan brownies rasa dipengaruhi oleh adanya komponen lain seperti susu, telur, bubuk cokelat dan minyak dengan jumlah yang sama pada tiap perlakuan. Menurut penelitian yang dilakukan oleh Pulungan, dkk (2012) brownies yang dibuat dengan substitusi bahan lokal lain seperti substitusi dengan tepung singkong, dan substitusi dengan tepung beras, rasa dari brownies tersebut tidak jauh berbeda dengan rasa dari brownies biasanya sama-sama disukai oleh panelis.

\section{c. Aroma}

Uji organoleptik aroma brownies kukus berkisar antara 3,25-3,525. Skor aroma tertinggi $(3,525)$ dihasilkan oleh formula 3 (brownies kukus substitusi tepung ubi jalar dengan perbandingan tepung terigu:tepung ubi jalar = 100:100). Panelis menilai aroma brownies kukus formula 3 disukai panelis. Skor aroma brownies kukus terendah $(3,25)$ dihasilkan oleh formula 4 (brownies kukus substitusi tepung ubi jalar dengan perbandingan tepung terigu:tepung ubi jalar $=150: 50)$. Tingkat skala kesukaan panelis adalah biasa saja terhadap aroma dari produk brownies.

Tingkat konsentrasi substitusi tepung ubi jalar termodifikasi tidak berpengaruh secara nyata terhadap aroma brownies kukus. Hal ini diduga karena aroma pada brownies dipengaruhi oleh penggunaan bahan cokelat batang dan cokelat bubuk dengan jumlah yang sama pada setiap perlakuan (Fathullah, 2013). Cokelat batang dan cokelat bubuk ketika dipanaskan akan menimbulkan aroma cokelat yang tajam sehingga aroma pada tepung ubi jalar termodifikasi tertutup.

Brownies kukus substitusi tepung ubi jalar ungu termodifikasi menghasilkan aroma brownies khas ubi jalar, semakin banyak konsentrasi substitusi maka aroma ubi pada brownies kukus akan semakin tercium oleh indra penciuman panelis. Aroma khas dari tepung ubi jalar berasal dari kandungan pati yang terdegradasi. Menurut Rodrigues, dkk (1988), pembentukan aroma dan flavor disebabkan oleh kandungan karbohidrat yang terdegradasi pada 
ubi jalar dan kandungan asam amino aromatik pembatas seperti lisin, metionin, sistein dan treonin yang terkandung didalamnya (Sulistiyo, 2006). Proses pembentukan aroma terjadi pada saat pencampuran bahan (mixing), sampai menjadi adonan dan akan berlangsung sampai proses pengukusan sehingga terbentuklah aroma yang khas (Hendrasty, 2003).

Aroma yang paling tidak disukai oleh panelis adalah brownies kukus formula 4 , hal ini diduga karena panelis cenderung tidak menyukai aroma langu yang diduga disebabkan oleh kadar air dari ubi jalar ungu. Ubi jalar mempunyai kandungan air yang cukup tinggi, sehingga bahan kering yang terkandung relatif rendah (Sulistiyo, 2006).

\section{d. Tekstur}

Tekstur berpengaruh penting terhadap tingkat kesukaan produk brownies kukus substitusi tepung ubi jalar ungu termodifikasi ditinjau dari tingkat kelembutan, keempukan, dan kekerasan, dan sebagainya. Tekstur yang baik dari brownies kukus adalah padat, moist, dan pori agak rapat serta kurang mengembang. Tekstur brownies kukus substitusi tepung ubi jalar ungu termodifikasi yang dihasilkan dipengaruhi oleh bahan-bahan yang digunakan seperti telur, margarine, tepung terigu dan tepung ubi jalar ungu termodifikasi. Secara umum semua formulasi brownies kukus substitusi tepung ubi jalar termodifikasi dapat diterima oleh panelis. Uji organoleptik tekstur brownies kukus berkisar antara 3,0375-3,4125.

Skor tekstur tertinggi $(3,4125)$ dihasilkan oleh formula 3 (brownies kukus substitusi tepung ubi jalar dengan perbandingan tepung terigu:tepung ubi jalar $=100: 100)$. Panelis menilai tekstur brownies kukus formula 3 disukai panelis, hal ini dikarenakan substitusi tepung ubi jalar sebanyak 50\% memiliki tekstur yang agak lembut bila dibandingkan dengan perlakuan yang lain. Skor tekstur brownies kukus terendah $(3,0375)$ dihasilkan oleh formula 4 (brownies kukus substitusi tepung ubi jalar dengan perbandingan tepung terigu : tepung ubi jalar = 150:50). Tingkat skala kesukaan panelis adalah biasa saja terhadap tekstur dari produk brownies, hal ini dikarenakan penggunaan tepung terigu dan tepung ubi jalar yang cukup berpengaruh pada tekstur.

Tingkat konsentrasi substitusi tepung ubi jalar termodifikasi tidak berpengaruh secara nyata terhadap tekstur brownies kukus. Hal ini diduga karena tekstur brownies dipengaruhi oleh tingkat kehalusan tepung yang digunakan, namun pada saat penggilingan tepung dilakukan dengan kecepatan yang sama sehingga tidak terdapat perbedaan partikel tepung yang menghasilkan tekstur brownies sama. Tekstur yang dihasilkan dari brownies kukus pada penelitian ini adalah lembut dan padat. Hal ini diduga karena adanya bahan tambahan seperti telur yang dalam fungsinya merupakan sebagai pelembut. Telur utuh mengandung $8-11 \%$ albumen (putih telur) dan 27-32\% kuning telur. Albumen berfungsi sebagai agensia pengeras, sedangkan kuning telur sebagai agensia pengempuk. Brownies kukus memiliki tekstur yang lembut karena dalam proses pengukusan brownies tidak menghilangkan banyak uap air karena proses pengukusan menggunakan uap air.

Menurut Desrosier (2008), tepung terigu merupakan struktur pokok atau bahan pengikat di dalam semua formula cake. Bahan yang digunakan untuk memproduksi cake memiliki pengaruh pengikat dan pengeras yang berbedabeda terhadap adonan. Penggunaan tepung terigu yang berlebih menghasilkan tekstur cake yang lebih lunak dan lebih beremah, sedangkan penggunaan tepung ubi jalar yang berlebih menghasilkan tekstur cake yang lebih keras dan tidak mengembang. Menurut Winarno, dkk (1989) dalam rakhmah (2012), tepung ubi jalar tidak memiliki protein gliadin dan glutenin yang dapat membentuk gluten, sedangkan tepung terigu mengandung protein dalam bentuk gluten. Gluten menyebabkan produk brownies kukus lebih mengembang. Selain itu kadar air dalam tepung ubi jalar ungu termodifikasi juga menentukan mengembang tidaknya adonan. Semakin tinggi kadar air di dalam tepung maka daya absorbsi air akan semakin berkurang begitu juga sebaliknya, dimana semakin tinggi absorbsi air maka akan menghasilkan peningkatan volume pada produk akhir (Desrosier, 2008).

\section{e. Penerimaan Keseluruhan}

Berdasarkan data uji organoleptik yang dilakukan oleh 20 panelis dari kelima sampel dengan 4 kali ulangan pada indikator penerimaan keseluruhan, skor penerimaan keseluruhan brownies kukus berkisar antara $(3,3625-3,6875)$. Panelis menilai penerimaan keseluruhan brownies kukus formula 3 disukai panelis. hal ini dikarenakan substitusi tepung ubi jalar sebanyak $50 \%$ memiliki warna dari brownies kukus yang menarik yaitu cokelat tua, rasa dan aroma brownies kukus formula 3 disukai panelis serta tekstur yang agak lembut bila dibandingkan dengan perlakuan yang lain.

Skor penerimaan keseluruhan brownies kukus terendah $(3,3625)$ dihasilkan oleh formula 
5 (brownies kukus substitusi tepung ubi jalar dengan perbandingan tepung terigu:tepung ubi jalar $=0: 200)$. Tingkat skala kesukaan panelis adalah biasa saja terhadap penerimaan keseluruhan dari produk brownies formula 5, hal ini dikarenakan penggunaan tepung ubi jalar yang cukup berpengaruh pada penerimaan keseluruhan brownies kukus substitusi tepung ubi jalar termodifikasi.

Hasil uji statistik menyatakan bahwa terdapat pengaruh nyata substitusi tepung ubi jalar termodifikasi terhadap penerimaan keseluruhan brownies kukus. Perbedaan panelis dalam menilai penerimaan keseluruhan brownies kukus pada penelitian ini disebabkan oleh perbedaan formula substitusi tepung ubi jalar ungu termodifikasi. Panelis lebih menyukai brownies kukus formula 3 dibandingkan dengan produk brownies kukus lainnya.

Penilaian panelis terhadap penerimaan keseluruhan merupakan hasil penilaian terhadap keseluruhan parameter organoleptik seperti warna, rasa, aroma dan tekstur. Brownies kukus formula 3 (brownies kukus substitusi tepung ubi jalar dengan perbandingan tepung terigu:tepung ubi jalar $=100: 100)$ secara keseluruhan disukai oleh panelis karena memiliki warna yang menarik yaitu cokelat, rasa manis, aroma wangi serta tekstur brownies yang lembut. Sedangkan brownies kukus formula 5 (brownies kukus substitusi tepung ubi jalar dengan perbandingan tepung terigu:tepung ubi jalar $=0: 200$ ) secara keseluruhan penilaian panelis adalah biasa saja, karena memiliki warna yang kurang menarik yakni kecokelatan, rasa brownies kukus yang kurang begitu manis, aroma yang biasa saja khas sehingga panelis kurang menyukai brownies kukus formula 5 .

\section{Indeks Glikemik (IG) dan Beban Glikemik (BG)}

\section{a. Kandungan Zat Gizi Brownies Kukus}

Berdasarkan hasil analisis, kadar karbohidrat pada brownies kukus formula 3 yaitu $35,62 \%$. Sumbangan energi dari karbohidrat pada brownies kukus formula 3 per 100 gram yaitu sebesar 368,75 kkal. Kadar karbohidrat yang terdapat pada brownies kukus formula 3 lebih rendah dibandingkan dengan penelitian yang dilakukan oleh Saragih (2011) yaitu sebesar $51,72 \%$. Protein berperan sebagai zat pembangun. Dalam 1 gram protein menghasilkan 4 kkal energi. Berdasarkan hasil analisis, kadar protein pada brownies kukus formula 3 adalah $9,88 \%$. Kadar protein pada brownies kukus formula 3 lebih tinggi dari penelitian yang dilakukan oleh Saragih (2011) yaitu sebesar $5,03 \%$.

Lemak memberikan nilai energi lebih besar daripada karbohidrat dan protein, yaitu 9 kkal per gram. Berdasarkan hasil analisis, kadar lemak pada brownies kukus formula 3 adalah $20,75 \%$. Kadar lemak yang terdapat pada brownies kukus formula 3 lebih rendah dibandingkan dengan penelitian yang dilakukan oleh Saragih (2011) yaitu sebesar 26,93\%. Kadar air pada brownies kukus formula 3 yaitu 27,49\%, lebih tinggi dibandingkan dengan penelitian yang dilakukan oleh Saragih (2011) yaitu $16,78 \%$.

Kadar abu merupakan unsur mineral sebagai sisa yang tertinggal setelah bahan dibakar sampai bebas karbon. Berdasarkan hasil analisis, kadar abu pada brownies kukus formula 3 yaitu sebesar $1,36 \%$, lebih rendah dibandingkan penelitian Saragih (2011) yaitu sebesar 2,39\%. Kadar abu yang terkandung dalam bahan pangan menunjukkan jumlah kandungan mineralnya. Serat kasar pada brownies kukus formula 3 yaitu $5,25 \%$, lebih rendah dibandingkan dengan penelitian yang dilakukan oleh Saragih (2011) yaitu 28,52\%.

Pada penelitian ini, jika pangan uji brownies kukus formula 3 dibandingkan dengan brownies kukus biasa, brownies kukus formula 3 kaya akan protein, karbohidrat serta lemak yang lebih rendah. Brownies kukus biasanya memiliki kandungan protein sebesar 5,03\%, karbohidrat sebesar 51,72\%, kadar air 16,78\%, serat 28,52\%, lemak 26,93\% (Saragih, 2011). Berdasarkan hasil pembahasan didapat bahwa brownies kukus formula 3 baik dikonsumsi karena mengandung protein, karbohidrat yang tinggi serta lemak yang lebih rendah dibanding dengan brownies kukus biasa.

\section{b. Indeks Glikemik}

Klasifikasi nilai IG makanan sebagai berikut: (1) IG rendah $(<55)$, (2) IG sedang (5575), dan (3) IG tinggi (>75). Brownies kukus substitusi tepung ubi jalar termodifikasi formula 3 memiliki IG sebesar 53,76\%. Berdasarkan klasifikasi nilai IG, brownies kukus formula 3 termasuk dalam IG rendah. Makanan dengan IG rendah akan menaikkan kadar glukosa darah secara perlahan, sebaliknya makanan dengan IG tinggi menaikkan kadar glukosa darah dengan cepat. Maka dianjurkan mengonsumsi makanan dengan IG rendah. Tujuannya adalah mengurangi beban glikemik makanan.

Gambar 3 menunjukan kurva rata-rata kenaikan/ penurunan kadar glukosa darah setelah 
pemberian roti tawar dan juga setelah pemberian brownies kukus formula 3. Respon glikemik ditunjukkan oleh kurva fluktuasi dari penyerapan glukosa dalam darah. Kurva fluktuasi dan area di bawah kurva tersebut dijadikan acuan dalam perhitungan nilai IG suatu produk pangan (Gambar 3). Konsumsi roti tawar memberikan efek lamanya kadar glukosa darah meninggi dan mendekati kadar glukosa darah normal setelah 2 jam konsumsi. Indeks Glikemik pangan ditentukan dengan membandingkan luas kurva respon glikemik selama dua jam setelah mengkonsumsi karbohidrat pangan uji dengan luas kurva respon glikemik selama dua jam setelah mengkonsumsi pangan acuan (Truswell, 1992). Grafik respon glukosa darah kedua bahan kemudian dihitung luas kurvanya. Kemudian dilakukan perhitungan indeks glikemik dengan kedua nilai tersebut. Indeks Glikemik brownies kukus formula 3 dengan roti tawar sebagai acuan adalah $53,7615 \%$.

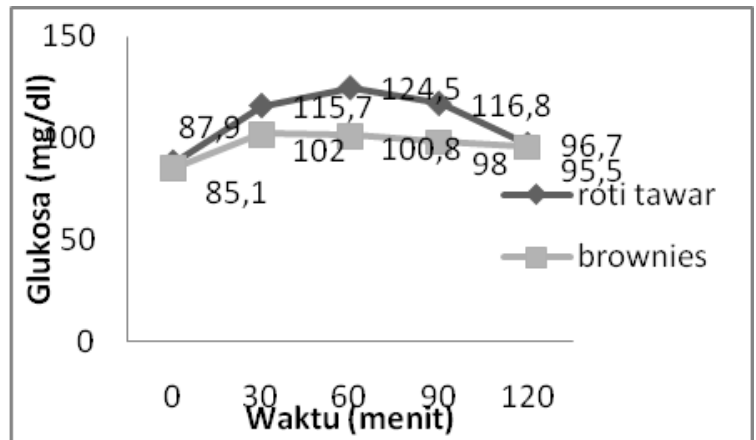

Gambar 3. Kurva Kenaikan/ Penurunan Glukosa Darah

Menurut Hoerudin (2012), pangan berIG rendah dan tinggi dapat dibedakan berdasarkan kecepatan pencernaan dan penyerapan glukosa serta fluktuasi kadarnya dalam darah. Faktor-faktor yang mempengaruhi IG suatu bahan pangan di antaranya kadar serat pangan, kadar protein dan lemak pangan, serta cara pengolahan. Rendahnya nilai IG diduga karena tepung ubi jalar termodifikasi mengandung serat makanan yang relatif tinggi disebabkan adanya perlakuan fermentasi ubi jalar ungu menggunakan BAL. Menurut Saxena et al. (1995), perlakuan pemberian bakteri Acetobacter xylinum dalam proses pembuatan dengan menggunakan metode fermentasi memiliki kemampuan untuk mempolimerisasi glukosa sehingga mampu mengubah menjadi selulosa. Menurut Gibson (2010), karbohidrat kompleks memiliki respon glukosa yang lebih kecil dalam darah. Karbohidrat yang terkandung dalam pangan tersebut akan dipecah dengan lambat sehingga pelepasan glukosa ke dalam darah berjalan lambat (Rimbawan dan Siagian, 2004). Sehingga makanan berbasis tepung ubi jalar termodifikasi lebih lamban dicerna dan lamban meningkatkan kadar gula darah.

Pangan rendah IG akan dicerna dan diubah menjadi glukosa secara bertahap, sehingga puncak kadar glukosa darah juga akan rendah, hal ini berarti fluktuasi peningkatan kadar glukosa relatif rendah. Sebaliknya, pangan tinggi IG akan dicerna dan diubah menjadi glukosa dengan cepat. IG memberikan informasi mengenai kecepatan perubahan karbohidrat menjadi glukosa darah, tetapi tidak memberikan informasi mengenai banyaknya karbohidrat dan dampak pangan tertentu terhadap kadar glukosa darah. Beberapa faktor yang mempengaruhi adalah kadar serat pangan, kadar amilosa dan amilopektin, kadar lemak dan protein. Kandungan serat pangan yang tinggi berkontribusi pada nilai IG yang rendah. Pangan dengan kandungan lemak dan protein tinggi cenderung memiliki IG lebih rendah dibandingkan dengan pangan sejenis yang berkadar lemak dan protein rendah.

\section{c. Beban Glikemik (BG)}

Beban glikemik (BG) didefinisikan sebagai IG makanan dikalikan dengan kandungan karbohidrat makanan tersebut. Tujuan BG yaitu menilai dampak konsumsi karbohidrat dengan memperhitungkan IG makanan. BG berbanding lurus dengan kandungan karbohidrat makanan. Semakin rendah kandungan karbohidrat semakin rendah BG maka semakin kecil suatu makanan yang disajikan memicu peningkatan kadar glukosa darah. Klasifikasi nilai BG makanan sebagai berikut: (1) BG rendah $(<11)$, (2) BG sedang (11-19), dan (3) BG tinggi (>20).

Dalam berat takaran saji 100 g BG brownies kukus formula 3 sebesar $19,15 \%$ termasuk dalam BG sedang. Sebelum menentukan nilai beban glikemik brownies kukus formula 3 dihitung terlebih dahulu nilai available karbohidrat. Nilai available karbohidrat didapat dari menggunakan metode by difference. Beban glikemik (BG) dapat memberikan informasi mengenai pengaruh konsumsi pangan terhadap peningkatan kadar glukosa darah. Konsumsi makanan rendah IG bertujuan untuk mengurangi BG. BG digunakan untuk menilai dampak konsumsi karbohidrat dengan memperhitungkan IG makanan. BG berbanding lurus dengan kandungan karbohidrat makanan. Semakin rendah kandungan karbohidrat semakin rendah BG maka semakin kecil suatu makanan yang disajikan memicu peningkatan kadar glukosa darah. 


\section{SIMPULAN}

Berdasarkan hasil penelitian dan pembahasan disimpulkan bahwa konsentrasi substitusi tepung ubi jalar ungu termodifikasi tidak berpengaruh nyata terhadap warna, rasa, aroma dan tekstur namun berpengaruh nyata terhadap penerimaan keseluruhan brownies kukus. Substitusi tepung ubi jalar ungu pada brownies kukus yang paling disukai didapat pada formula 3 .

Indeks glikemik brownies kukus substitusi tepung ubi jalar ungu termodifikasi yang paling disukai sebesar 53,76\% (rendah). Beban glikemik brownies kukus substitusi tepung ubi jalar ungu termodifikasi yang paling disukai sebesar 19,15\% (sedang). Kandungan gizi brownies kukus

\section{DAFTAR PUSTAKA}

Badan POM. 2011. Peraturan Kepala Badan Pengawas Obat Dan Makanan Republik Indonesia Nomor HK 03.1.23.12.11.09909. Metode Standar Penentuan Indeks Glikemik Pangan.

BPS. 2013. www.bps.go .id (Diakses 15 Januari 2016).

Brand, J.C., Crossman, S., Pang E., Colagiuri S and Truswell A.S. 1985. Food Processing and the glycemic index.Am. J. Clin. Nutr. 42.

Desrosier. 2008. Teknologi Pengawetan Pangan. Penerjemah M. Muljohardjo. Jakarta; UIPress.

Fathullah, Ali. 2013. Perbedaan Brownies Tepung Ganyong Dengan Brownies Tepung Terigu Ditinjau dari Kualitas Inderawi dan Kandungan Gizi. Skripsi. Semarang: Fakultas Teknik, Universitas Negeri Malang.

Gibson, N. 2010. Development of a rapid assessment method for the glycaemic index. Thesis. Pretoria: University of Pretoria

Hendrasty, Henny Krissetiana. 2003. Teknologipengolahan Pangan: Tepung Labu Kuning. Yogyakarta: Kanisius.

Hoerudin. 2012. In Vitro Digestion Study Of Factors Affecting Availability Of Sugars From Fruits and Vegetables. In Phd Thesis, School Of Agriculture and Food Sciences. The University Of Queensland: Brisbane, Queensland, Australia.

Lutfika, Evrin. 2006. Evaluasi Mutu Gizi Dan Indeks Glikemik Produk Olahan Panggang Berbahan Dasar Tepung Ubi Jalar substitusi tepung ubi jalar ungu termodifikasi yang paling disukai (Formula 3) meliputi kadar air $(27,49 \%)$, kadar abu $(1,36 \%)$, kadar protein $(9,88 \%)$, kadar lemak $(20,75 \%)$, serat kasar $(5,25 \%)$ serta karbohidrat total sebesar $(35,62 \%)$.

\section{SARAN}

Perlu dilakukan pendiversifikasian produk brownies kukus substitusi ubi jalar termodifikasi dengan pengurangan konsentrasi pemberian gula, sehingga dapat dijadikan snack untuk penderita diabetes mellitus serta perlu dilakukan penelitian lebih lanjut tentang aktivitas antioksidan brownies kukus substitusi ubi jalar termodifikasi.

(Ipomoea Batatas L.) Klon Unggul BB00105.10. Skripsi. Institut Pertanian Bogor. Bogor.

Pratiwi, Novia Utami. 2015. Pengaruh Substitusi Tepung Bengkuang terhadap Kualitas Brownies Kukus. Skripsi. Universitas Negeri Padang. Padang.

Pulungan, Elvina., Albiner Siagian dan Ernawati Nasution. 2012. Uji Daya Terima dan Nilai Gizi Brownies Singkong. Skripsi. Fakultas Kesehatan Masyarakat. Universitas Sumatera Utara. Medan.

Rakhmah, Yaumil. 2012. Studi Pembuatan Bolu Gulung dari Tepung Ubi Jalar (Ipomoea batatas L). Skripsi. Fakultas Pertanian, Universitas Hasanudin. Makasar.

Rimbawan dan Siagian, Albiner. 2004. Indeks Glikemik Pangan. Bogor: Penebar Swadaya.

Rodriques P.B.L Raina, Eb Pantatisco dan M.B Balt. 1998. Mutu Buah-Buahan Mentah untuk Pengolahan Fisologis Lepas Panen. Yogyakarta: Gajah Mada Univ Press.

Saragih I.P. 2011.Penentuan Kadar Air Pada Cake Brownies Dan Roti Two In One Nenas Dan Es. Skripsi Sarjana, Fakultas Teknologi Pangan, Sumatra Utara.

Saxena, IM, Kudlicka, K., Okuda K., dan Brown, RMJR. 1995. Karakterisasi Gen di Sintesis Selulosa Operon (ACS Operon) dari Acetobacter xylinum: Implikasi untuk Kristalisasi Selulosa. Journal of Bacteriology, ay 176.

Suismono. 2001. Teknologi pembuatan tepung dan pati ubi-ubian untuk menunjang 
ketahanan pangan. Majalah Pangan. Vol. X No. 37:37-49. Jakarta: Puslitbang Bulog.

Sukarsih. 2009. Brownies Kukus dari Tepung Ubi Jalar. Skripsi Fakultas Tenik Universitas Makasar.

Sulistiyo, C. N. 2006. Pengembangan Brownies Kukus Tepung Ubi Jalar (Ipomoea Batatas L.) di PT. Fits Mandiri Bogor. Skripsi. Fakultas Teknologi Pertanian, IPB, Bogor.

Truswell, As. 1992. Glycaemic Index Of Foods. Eur. J. Clin. Nutr, Vol. 46, Suppl. 2: S 91101.

Widodo, Y. dan E. Ginting. 2004. Ubi Jalar Berkadar Beta Karoten Tinggi sebagai
Sumber Vitamin A. Balai Penelitian Tanaman Kacang-kacangan dan Umbiumbian, Malang.

Winarno, F.G. 2002. Kimia Pangan Dan Gizi. Jakarta: Gramedia Pustaka Utama.

Yuwono, M, Nur B dan Lily A. 2010. Pertumbuhan dan Hasil Ubi Jalar (Ipomoea Batatas (L.) Lam.) pada Macam dan Dosis Pupuk Organik yang Berbeda Terhadap Pupuk Anorganik. http://images.soemarno.multiply.multiplyc ontent.com/ (Diakses Tanggal 10 September Januari 2016). 